\title{
Advertising and Methodology What advertising has to teach us about (the study of) Thai Buddhism Part one
}

\author{
Miloš Hubina
}

https://doi.org/10.14712/25704893.2017.3

\begin{abstract}
In this paper I make proposals regarding further advances in the studies of Theravada Buddhism along the lines suggested by Justin McDaniel in his The Lovelorn Ghost and the Magical Monk (2011). The benefits of McDaniel's approach lie in his de-emphasis of doctrinal tradition and his focus on local frames of reference in explaining Thai Buddhism. Its faults lie in a disregard for the developments outside the socio-cultural paradigm. I argue for the integration of socio-cultural and naturalist approaches to the study of religion. Balancing the over-accentuation of the explanatory power of either socio-cultural or cognitive concepts, such integration would also permit a move from the socio-cultural metaphorical models to causal and more controlled explanations of religious phenomena.

I illustrate my suggestions through an example of a Thai wat (shrine/monastery). One of these suggestions, implied by the de-emphasis of the doctrinal tradition, is to recognize the predominantly advertising and ritualistic function of wats' visuals, effigies, and architecture rather than reading them as symbolic expressions of doctrinal tenets.
\end{abstract}

Keywords: Thailand, Buddhism, Theravada, Advertising, Wat, Shrine, Cognitive Science of Religion

\begin{abstract}
Abstrakt: Ve svém článku se pokouším o další rozvinutí metodologie studia thajského buddhismu navrhnuté Justinem McDanielem v jeho knize The Lovelorn Ghost and the Magical Monk (2011). Pozitivem prístupu vypracovaného McDanielem je, že ve snaze osvětlit charakter thajského buddhismu přesouvá důraz ze studia doktrinální tradice na prvky lokálního kontextu. Negativem pak je opomíjení výsledků bádání a teoretických postupů souvisejících bezprostředně s jím navrhovanými řešeními, formulovanými však mimo standardní socio-kulturní paradigma. Na príkladu situace $\mathrm{v}$ thajském watu (klášter/ svatyně) Thámai ilustruji možnou integraci socio-kulturních a naturalistických prístupů, která umožnuje postup od užitečných metafor socio-kulturních modelů ke kauzálním a více kontrolovatelným vysvětlením náboženských fenoménů a vyvažuje přeakcentovávání explanační síly jak sociokulturních, tak kognitivních konceptů. Jedním $\mathrm{z}$ důležitých motivů, které bezprostředně vycházejí z metodologického odklonu od důrazu na doktrinální stránku při vysvětlování „žité“ náboženské tradice, je potřeba rozeznat primárně reklamní a rituální charakter thajských buddhistických vizuálů, architektury a podobizen, které tradičnější prrístup interpretuje jako symbolické vyjádření článků doktríny.
\end{abstract}

Klíčová slova: Thajsko, buddhismus, theravada, reklama, wat, svatyně, kognitivní religionistika

Received: 17 March 2016, Accepted: 21 April 2016, Published online: 26 June 2017

Miloš Hubina, Ph.D., College of Religious Studies, Mahidol Univerisity, Thailand.

E-mail: miloshubina@yahoo.com

(c) 2016 Author. This is an open-access article distributed under the terms of the Creative Commons Attribution License (http://creativecommons.org/licenses/by/4.0), which permits unrestricted use, distribution, and reproduction in any medium, provided the original author and source are credited. 
Ludwig Wittgenstein once likened Philosophers to "little children, who first scribble random lines on a piece of paper with their pencils, and now ask an adult 'What is that?'”" Anthropology involves similar scribbling of random lines, naming them "Buddhism", "Animism", "Christianity", and the like and asking "WHERE is that?"

"Where" asks mostly about geographical and historical locations but sometimes it also has a conceptual dimension, an inquiry about the level of abstraction at which these concepts have meaning and explanatory power. Scholars of Theravāda Buddhism find the core of the tradition in its scriptural articulation of soteriology and ontology ${ }^{2}$ which, as they believe, can be determined with reasonable precision; the canon's ambiguity and traces of historical developments notwithstanding. Associated belief often holds that the doctrinal view is, in the real world, entertained by a "reflective few" and this "great tradition" serves scholars as a backdrop for an analysis of derivative forms of the "folk" or the "little" tradition. ${ }^{3}$ This view still dominates studies of Theravāda Buddhism. Indeed, there have always been disconcerting voices. Many of them, however, implicitly endorsed the model. When the late Thomas Kirsch complained about the clarity of employed definitions, he didn't think that the criticism should also involve the concept of Buddhism. He maintained that scholars "recognize a degree of internal complexity in each of the two components [Buddhism, Animism], apparently the Buddhist one has been identified through a number of unambiguous criteria, while the non-Buddhist one seems to have a residual character. That is, any religious element not identifiable as Buddhist is classed as 'non-Buddhist' or 'Animist'." 4 When Obeyesekere $^{5}$ equated great tradition with canonical texts and idealized sangha, denying at the same time its social embodiment, he has attributed the two an unrealistic level of homogeneity creating thus a comparative background for the local "little traditions". Tambiah, panning the concept of great tradition as "static and profoundly a-historical", ${ }^{6}$ still mapped selected Buddhist texts on contingent historical, political, and social

1 Ludwig Wittgenstein, Philosophical Occasions 1912-1951, edited by James Klagge and ALFRED NORDMAN, Indianapolis: Hackett Publishing 1993, p. 193.

2 Brian Morris, Religion and Anthropology, New York: Cambridge University Press 2006, 350 p.; Richard Gombrich, How Buddhism Began: The Conditioned Genesis of the Early Teachings, London, New York: Routledge 2006 (first published 1996), 180 p.; Barend J. Terwiel, Monks and Magic: An Analysis of Religious Ceremonies in Central Thailand, Third Revised edition, Bangkok: White Lotus 1994 (first published 1975), 302 p.; MELford E. SpIro, Buddhism and Society: A Great Tradition and its Burmese Vicissitudes, Second expanded edition, Berkeley: University of California 1982 (first published 1970), $510 \mathrm{p}$.

3 Little traditions, as well as the processes through which they have evolved, have received various appellations ("syncretism", "inspiriting”, "localization", “decentralization”, "hybridization", etc.). When not synonymic the terms intend to capture cultural differences between these developments insignificant to this paper. I will therefore use the term "syncretism" throughout this text. "Hybridization", as will be discussed later, is the only concept that cannot be substituted by "syncretism" as it is intended to limit the applicability of the two-traditions model.

4 Thomas A. KIrsch, "Complexity of Thai Religious System", The Journal of Asian Studies 36 (2, 1977): p. 241-266.

5 Gananath Obeysekere, "The Great Tradition and the Little”, The Journal of Asian Studies 22 (2, 1963): p. 139-153.

6 Stanley J. Tambiah, Buddhism and the Spirit Cults in North-east Thailand, Cambridge University Press 1970, p. 370. Emphasis original. 
realities, assigning the texts the paradigmatic role of great tradition. As scholars have noted, Tambiah understood Buddhism as a "culturally sophisticated force impacting through time on local animistic worlds", ${ }^{7}$ a view fully compatible with Thomas Kirsch's metaphor of "upgrading"8 and revealing Tambiah's vertical outlook: social reality produces texts reflective of their historical origins but when these conditions have faded over time the texts remain, as ideals looked up to by the little tradition.

Even more radical critics shy away from questioning the model's theoretical feasibility and only claim that "social reality has outgrown this proposed model." The proposed alternative to the outgrown model recognizes that the religious dynamic is no more fully describable in terms of "vertical" interactions between Theravāda institutions and doctrines on the one hand and folk religious practices on the other. It introduces a "third place" or "hybrid", irreducible to any of the two components of the outdated syncretistic model. Quoting Bhaba, Kitiarsa explains:

"'Here the transformational value of change lies in the re-articulation, or translation, of elements that are neither the One [...] nor the Other [...] but something else besides which contests the terms and territories of both'. ${ }^{10}$ In the third space, 'something else besides' is formed out of various components and elements with specific new sets of different meanings and connotations." ${ }^{\prime \prime}$ As a new cultural reality the third space invalidates the preterit speculations about the eventual prevalence of one or the other component of the old model..$^{12}$ In the real world it represents a diversified market of religious practices which cannot be classified as "corrupted Buddhism" or "indigenous tradition". However, here we also find "conventional Theravada Buddhism, state, and Sangha authorities" and "multi-original religious beliefs"13 as two separable, albeit not dominant, forces governing the religious dynamics.

The "WHERE", in socio-culturally oriented Buddhist studies, thus doesn't insinuate a doubting of "whether". It fully affirms the existence, and only asks about spatiotemporal localizations. "Buddhism" is regarded a real category definable on the basis of doctrinal tenets. Exceptions to this view are very few..$^{14}$ The most recent refusal

7 James Taylor, "Cyber-Buddhism and Changing Urban Space in Thailand" (online), Space and Culture 6 (3, 2003; accessed May 2016): p. 292-308, available online at http://sac.sagepub.com /cgi/content/abstract/6/3/292, p. 53.

8 TAYLOR, "Cyber-Buddhism and Changing Urban Space in Thailand", p. 265. See also note 12.

9 Pattana Kitiarsa, "Beyond Syncretism: Hybridization of Popular Religion in Contemporary Thailand”, Journal of Southeast Asian Studies 36 (3, 2005): p. 466. Emphasis mine.

${ }^{10}$ Номі K. Внавна, “The commitment to theory”, New Formations 5 (1988): p. 13.

11 Kitiarsa, “Beyond Syncretism”, p. 468.

12 "Kirsch once predicted that 'the Buddhaization process' would 'upgrade' Thai religion, facilitate the spread of Buddhism among Thai peoples and transform their religious and social system. Modernization in Thailand, he argued, served to emphasize 'the central position of Buddhism in Thai religion and society and to elevate the level of religious sophistication within the Sangha'. However, this type of prophetic prediction is far from the reality. Since the 1990s, the Sangha has no longer been the sole authoritative force monitoring and handling Buddhist affairs." Kitiarsa, "Beyond Syncretism", p. 464-465.

13 Kitiarsa, "Beyond Syncretism”, p. 468.

${ }^{14}$ For an exception see, for example, Rita Langer: "It seems to me that the Buddhist texts are as varied and rich as the practice: reaching from doctrinal lists to anecdotes and stories. They incor- 
of the "old model" causing a splash in the field of studies of Thai Buddhism is Justin McDaniel's book The Lovelorn Ghost and the Magical Monk ${ }^{15}$ which I will discuss in some detail presently.

A consistent criticism making an explicit claim that "'Buddhism' is not an essentialist category, and we cannot hope to reconstruct a coherent 'Buddhist doctrine' on the basis of literary documents,"16 however, has come from the cognitive studies of religion. Two issues are crucial to this argument:

First, that the high degree of religious canons' interpretive flexibility prevents an unequivocal identification of traditions on the basis of their doctrinal tenets. As Scott Atran ${ }^{17}$ has pointed out, this view goes as back as to early rational and empirical philosophers such as Descartes (Les Principles de la Philosophie, 1681) and Hume (An Inquiry Concerning Human Understanding, 1758). But it was Dan Sperber who revived the idea. Since his famous argument ${ }^{18}$ for the semi-propositional character of religious beliefs wherein the content is not always clearly understood but is believed to be true under a correct interpretation, many scholars have argued to the effect that religious representations include "complex concepts with no one clear representation, and involve inferential gaps, which means that people are often uncertain about the propositions that can be directly derived from religious statements they regard as being true,${ }^{19}$ it is therefore always possible to find radically new interpretations for religious beliefs which are challenged by some piece of evidence."20

Secondly, it has been pointed out that ethnography evidences only an insignificant interest of believers in doctrinal tenets. ${ }^{21}$ Without motivational impact the doctrine has little relevance in explaining actual religious views and practices.

As a result, "Buddhism", "Hinduism", "Christianity" and similar concepts can only be ascribed a taxonomical function. They are not concepts to explain anything. While it is legitimate to enlist "paticcasamuppāda", "anattā", "sūnyatā", "kamma", "nibbāna",

porate ghosts, demons and other supernatural beings; they record the performance of miracles, the display of supernatural powers, and very moving stories. They give advice on how to reach meditational achievements as well as how to deal with everyday problems.” Rita LANGER, Buddhist Rituals of Death and Rebirth: Contemporary Sri Lankan Practice and its Origins, London, New York: Routledge 2007, p. 4-5.

15 Justin T. McDaniel, The Lovelorn Ghost and the Magical Monk, New York: Columbia University Press 2011, $327 \mathrm{p}$.

${ }^{16}$ Ilka PyysiäInen, Supernatural Agents: Why We Believe in Souls, Gods, and Buddhas, Oxford, New York: Oxford University Press 2009, p. 137.

17 Scott Atran, In Gods We Trust: The Evolutionary Landscape of Religion, New York: Oxford University Press 2004, p. 94.

${ }^{18}$ DAN Sperber, Rethinking Symbolism, Cambridge, New York: Cambridge University Press 1975, 153 p.; DAn Sperber, "Apparently Irrational Beliefs", in Martin Hollis and Steven Lukes (eds.), Rationality and Relativism, Oxford: Blackwell Publishers 1993 (first published 1983), p. $149-180$.

19 Pascal Boyer, The Naturalness of Religious Ideas: A Cognitive Theory of Religion, Berkeley: University of California Press 1994, p. 42-49.

${ }^{20}$ Ilka PyysiäInen, How Religion Works. Towards and New Cognitive Science of Religion, Brill 2003, p. 69-70.

${ }^{21}$ See Pascal Boyer, Religion Explained: The Evolutionary Origins of Religious Thought, New York: Basic Books 2001, 375 p. 
and some other terms as pertaining to Buddhist doctrinal narrative it would be incorrect to claim that they define "Buddhism" as concepts with meaning unequivocally encoded in canonical texts and with direct impact on peoples' lives.

The Pâli canon, works of art, or Buddhist philosophy play a marginal role in the lives of the Thais. Scholars approaching buildings, effigies, and visuals of Thai wats (shrine/monastery) as expressions of doctrinal tenets, a subject-matters of art-history or iconography capture only an extremely tiny fragment of their actual function. ${ }^{22}$ I will illustrate, through a case study of wat Thāmai (วัดท่า ไม้) in Samut Sakhon province, that tiny objects like car-stickers, billboards, banners, signs on the walls, "uncanonical" representations of the Buddha, and doctrinally unapproved practices are more potent sources for understanding Thai Buddhism than their frequent derogatory labelling as hapless symptoms of commercialism and commodification suggest. This is also an approach McDaniel advocates in his book.

In his The Lovelorn Ghost McDaniel has outlined a program for study of Thai Buddhism divorced from the assumptions of pure Buddhism, Hinduism, Animism or considerations of canonical traditions. Instead, he concentrates on local structures, emphasizing that the religious phenomena typically marginalized as unorthodox, commerce-driven or residual may in fact define mainstream religious tradition. Given the feeble presence of the Păli canon in Thai religious history ${ }^{23}$ this is a right move. Turning away from doctrinal tenets, $\mathrm{McDaniel}$ suggests reading religious phenomena as expressions of a system of local values or, as he calls it, "repertoire". In his own words:

"Local repertoires are characterized, but not defined, by their emphasis on security, heritage, graciousness, and abundance (khwam plotphai or kan pongkan, moradok, udom sombun $[\mathrm{sic}],{ }^{24} \mathrm{khwam}$ sawatdiphap or kreng chai). I do not see these as universal or static Thai values or traits, but they are relatively useful technologies of enactment or perhaps axiomatic modes of articulation that characterize the motivation of stagers, performers, fans, experts, and devotees of Thai Buddhist religions. They are heuristic categories that we should not assume participants in Thai Buddhist culture

${ }^{22}$ There are exceptions but the described tendency is overwhelming. Even monks praised for their knowledge are usually approached for reasons other than clarification of philosophical intricacies, most often for the sake of a meritorious act.

23 "There is little evidence that the Pali Canon was available to and accessible by the majority of Thais in, or previous to, 1902. The canon was rarely found as a set in one monastery, and the authoritative parts of the canon were not commonly agreed on at any time in Thai history." Justin T. MCDaniel, "Buddhism in Thailand. Negotiating the Modern Age", in Stephen C. Berkwitz (ed.), Buddhism in World Cultures: Comparative Perspectives, Santa Barbara: ABC-CLIO 2006, p. 103. See also Justin T. MCDAniel, Gathering Leaves \& Lifting Words: Histories of Buddhist Monastic Education in Laos and Thailand, Seattle: University of Washington Press 2008, p. 102-103. Concerning the utilization of the available canonical text McDaniel argues that "Lao and Northern Thai teachers were not primarily concerned with transmitting whole canonical Pali Buddhist texts; rather, they drew Pali terms and phrases from a wide selection of canonical and extra-canonical texts in order to teach their own idea of Buddhism. Instead of transmitting an integral and received tradition, they took bits and pieces of the received tradition in service of their own local rituals, ethics, and social norms." MCDANIEL, Gathering Leaves \& Lifting Words, p. 121.

${ }^{24} \mathrm{McD}$ aniel switches the Thai words for "graciousness" and "abundance" here. 
necessarily would use to describe their own values but ones with which most would certainly agree. They are not foreign concepts but demotic modifiers. They might not be the ideal Buddhist values in which they are supposed to believe, but they help give shape and significance to what many Thais cherish and honor."25

He further proposes that the differential popularity of wats, monks and religious objects positively correlates with the degree to which they exhibit these values. ${ }^{26}$

I agree that mapping religious representations and practices on the system of local values and cultural patterns is a more productive strategy than tracing their deviations from, or compliance with, authoritative but protean norms the believers have never heard of or attempted to understand. Thai wats, monks, lineages, religious objects, and sites are typically renowned for their idiosyncratic features, rituals, and powers advertised by variety of signifiers, and surely not for their ingenuity in representing doctrinal tenets. A casual glance at the doctrinal literacy of Thai Buddhists (laypeople or monastics) also indicates against interpreting all these objects and people as efficacious didactic symbols and agents. Yet, I also believe that McDaniel, locked in the socio-cultural methodological framework, misses an opportunity to articulate the new directions in the study of Thai Buddhism with force and clarity.

Neglecting independent anthropological and psychological studies, he derives the list of values from his interpretation of Thai texts, stories, gossips, and cultural habits which makes his argument overly subjective and, since most of his illustrations come from religious context, even circular. Discussing a famous monk's choice of a protective chant he, for example, argues:

"We don't know why Somdet To thought this particular text was so important. $\mathrm{He}$ could have picked a chant from the canonical suttas or even an Abhidhamma text. There is not a clear reason why he simply did not elevate a well-known protective (paritta) incantation like the Rattana, Mora, or Mangala suttas. It could have been that Jinapañjara mentions the seven most famous paritta texts. It could have been seen by him as superior because it invokes these texts, as well as the power of the Buddha, his eighty major disciples, and the total power of the Dhamma and the sangha. Here we certainly see the Thai values of abundance, security, and heritage. Perhaps he saw the Jinapañjarai as powerful because of its all-encompassing message."27

In fact, we don't see any of that, let alone certainly, since McDaniel fails to provide indicators of the values. Not all instances of valuing a high quantity reflect the "value of abundance". A student's wish to obtain maximum points and score high on the final exam are hardly motivated by the "value of abundance". Is the doctrine of the Trinity, postulating three persons instead of one an expression of the value of abundance? Or is it rather the Hindu pantheon with its uncounted number of deities? Its shrines housing a plethora of effigies? And how about the sober mosque with no effigies but "abundant" space? Do they all express the same value? How do we know?

\footnotetext{
${ }^{25}$ MCDaniel, The Lovelorn Ghost and the Magical Monk, p. 13-14.

${ }^{26}$ MCDAnIEL, The Lovelorn Ghost and the Magical Monk, p. 13.

${ }^{27}$ MCDANIEL, The Lovelorn Ghost and the Magical Monk, p. 88.
} 
None of McDaniel's proposals is falsifiable. If he uses the fact that Somdet To was a vigorous producer of magical amulets to support his thesis, ${ }^{28}$ should we count amulets other monks produce to compare them with their popularity? I know of too many largely unknown monks producing amounts of amulets to bother. For a large production and distribution of amulets to be even noted the monk has to be famous in the first place.

Similarly, pointing out that "Somdet To is described as handsome and physically impressive" 29 to illustrate the causal function of the value of "graciousness" amounts to determining arbitrarily the cause and effect. The characteristic of physical attractiveness could have been attributed to the elderly monk because he was famous and venerated rather than other way round.

Much of McDaniel's argument is plainly circular. He derives most of the values from religious context and then uses them to explain religious phenomena. Other statements are just truisms or tautologies as when he says that reciting protective verses reflects the value of security.

Certainly, in a good habit of many socio-cultural or "postmodern" writers, he hedges himself against criticism by declaring that "readers of the following chapters may see my evidence as invoking other values. Indeed, I hope that readers will take the evidence I provide as a platform on which to debate the nature of Thai Buddhist ethics or even the very idea that there is a 'Thai way' of being Buddhist." 30

Since McDaniel doesn't spell out the circumstances under which an alternative reading of the evidence is possible, it amounts to "anything goes". And there where anything goes can be many voices but surely no discussion.

As key explanatory concepts, the "values" to be convincingly asserted require more than a "reading of [...] idiosyncratic narratives." 31

In the light of the Thais' preoccupation with their own "nature" and the system of values McDaniel's neglect of independent researches on the Thais' value system is particularly conspicuous. A vast amount of studies and comments on "Thainess", scholarly, professional, and amateurish, has sprouted out of this concern. Constructing a national identity, "Thaification", has figured high on the political agenda since the early twentieth century. Also in this context, the National Identity Board was established in 1980 and as Simpson and Thammasathien observe, "the level of concern about Thai national identity remains very high and there is constant public discussion of the identity issues". ${ }^{2}$

${ }^{28}$ MCDANIEL, The Lovelorn Ghost and the Magical Monk, p. 67.

${ }^{29}$ MCDANiEL, The Lovelorn Ghost and the Magical Monk, p. 68.

${ }^{30}$ McDANiEL, The Lovelorn Ghost and the Magical Monk, p. 14.

${ }^{31}$ MCDANIEL, The Lovelorn Ghost and the Magical Monk, p. 15.

32 Andrew Simpson and Noi Thammasathien, "Laos and Thailand", in Andrew Simpson (ed.), Language and National Identity in Asia, Oxford, New York: Oxford University Press 2007, p. 406. 
The second problem with McDaniel's interpretation is that while he sets out to answer the questions "Why are some monasteries much busier than others? Why are some monks much more famous than others? Why did certain liturgies, rituals, texts, images, amulets persist and other disappear? [...] What do most Buddhists do?", ${ }^{33}$ McDaniel fails to take into account the general cognitive constrains on transmission of cultural representations.

Three basic corrections thus follow from these observations if we are to advance along the suggested line of analysis: 1. placing socio-cultural explanations of cultural representations into a broader cognitive framework, 2. triangulating postulated cultural values and patterns, ${ }^{34}$ and 3 . since the structural correlations between cultural values and the studied religious phenomena do not explain these phenomena, a formulation of a causal theory explaining the correlations. As Melford Spiro summarized the last point some time ago, "[t]hose structural accounts that delineate the configuration in, or relationships among, a set of sociocultural variables are essentially descriptive rather than explanatory - unless of course some theory, causal of functional, is offered to explain the configuration." ${ }^{35}$

To illustrate this point: socio-cultural accounts typically operate on an abstract "Buddhism - animism" level of analysis. Terwiel ${ }^{36}$ thus, for example, explains Thai "syncretistic" or "magico-animistic" Buddhism as a result of filtering Buddhist tenets through the selective matrix of "magico-animism". This, obviously, is not an explanation but a metaphor and whatever epistemic importance of metaphors, nothing in how "Buddhism" or "magico-animism" are, or can be, defined suggests how "animism" executes this power and why "those aspects of religious culture that have been the least publicly institutionalized or supported, those that are the least modern and rational, are those that seem most capable surviving radical social and political change?"37

If institutionalization is supposed to stabilize mental and public religious representations and still it is the least institutionalized traditions that survive social and political changes, Holt's question - saved from its trivial rendering "why are social

\footnotetext{
${ }^{33}$ McDAnieL, The Lovelorn Ghost and the Magical Monk, p. 6.

${ }^{34}$ Values will be understood throughout the text as "choice preference and conception of the desirable" (Suntaree Komin, Psychology of Thai People: Values and Behavioral Patterns, Bangkok: NIDA 1990, p. 21) and patterns as behavioral habits unrelated to any specific, consciously held value system.

35 Melford E. Spiro, "Religion: Problems of definition and Explanation”, in Michael Banton (ed.), Anthropological Approaches to the Study of Religion. London, New York: Routledge 2004 (first published 1966), p. 100.

${ }^{36}$ Barendt J. Terwiel, "A Model for the Study of Thai Buddhism", The Journal of Asian Studies 35 (3, 1976): p. 391-403; TERWIEL, Monks and Magic, 302 p.

${ }^{37}$ Clifford Holt, Spirits of Place: Buddhism and Lao Religious Culture, Honolulu: University of Hawaii 2009, p. 16; emphasis original. Some scholars, e.g., Holt, explain these interactions in more concrete socio-political terms. Holt identifies the Buddhist resistance to corrosive influence of animism with the power of the monarchy - the main vehicle of Buddhism in Theravāda countries. But he doesn't explain the mechanisms through which "animism" constantly threatens the "purity" of Buddhism.
} 
institutions threatened by abrupt social changes?" - indicates cognitive and other psychological structures underlying socio-cultural stabilizing dints. Separating culture from its psychological and biological embedding prevents the step from metaphorical to real causal explanation of religious dynamics. ${ }^{38}$ The cognitive science of religion can equip socio-cultural models with an important set of causal explanations ${ }^{39}$ though, of course, a cultural-level analysis of concepts and cultural model's mutual reinforcing and immunization against these general cognitive constraints is possible and much desired. But it requires much subtler than the Buddhism-Animism conceptual schema. ${ }^{40}$ More refined conceptual analysis may permit linking specific cultural representations with more fundamental general psychological drives and thus explain the former's motivational function. ${ }^{41}$

Attempts at integrating general cognitive and culture specific explanations have mostly been made by cognitive scientists. ${ }^{42}$ Socio-cultural scholarship remains adamant in its paradoxical "anti-reductionist' methodological exclusivism", particularly for studies of Theravāda, but I believe we can generalize this to a much wider area.

I am not going to argue from the perspective of cognitive science of religion; indeed, there is not a universal consensus and the cognitive science of religion is a complex and constantly evolving field. ${ }^{43}$ However, I want seriously consider its "basic claim about the constraining influence of everyday cognitive functioning upon religion". ${ }^{44}$ What I am going to say will resonate with ideas variously articulated by scholars such as Sorensen, Barrett, Barrett, Talmont-Kaminski, Jensen,

${ }^{38}$ See also Pascal Boyer, "Cognitive Aspects of Religious Symbolism”, in Pascal Boyer (ed.), Cognitive Aspects of Religious Symbolism, Cambridge, New York: Cambridge University Press 1993, p. 4-47.

${ }^{39}$ While historical studies of religion can, in turn, supply material for testing and refining cognitive theories. See e.g., Thomas Lawson, "Explanatory Pluralism and the Cognitive Science of Religion", in Dmitris Xygalatas and William W. McCorkle Jr. (eds.) Mental Culture. Classical Social Theory and the Cognitive Science of Religion, Durham: Acumen 2013, p. 11-32; or DAviD Sloan Wilson, Darwin's Cathedral: Evolution, Religion, and the Nature of Society, Chicago: The University of Chicago Press 2002, 268 p.

${ }^{40}$ See e.g. Jesper Sørensen, "Religion, Evolution, and the Immunology of Cultural Systems", Evolution and Cognition 210 (1, 2004): p. 61-73.

${ }^{41}$ See Roy G. D’Andrade, "Schemas and Motivations", in Roy G. D’Andrade and Claudia Strauss (eds.), Human motives and Cultural Models, Cambridge: Cambridge University Press 1997 (first published 1992), p. 23-44.

${ }^{42}$ William Paden is one of a very few notable exceptions here. William E. Paden, "Connecting with Evolutionary Models", in Villi Braun and Russell T. McCutcheon (eds.), Introducing Religion. Essays in Honor of Jonathan Z. Smith, London, Oakville: Equinox Publishing 2008, p. 416-417; William E. Paden, "The Prestige of the Gods: Evolutionary Continuities in the Formation of Sacred Objects”, in ARMin W. GeERTz (ed.), Origins of Religion, Cognition and Culture, Durham: Acumen 2013, p. 82-97; William E. Paden, New Patterns for Comparative Religion: Passages to an Evolutionary Perspective, London, New York: Bloomsbury Academic 2016, $253 \mathrm{p}$.

${ }^{43}$ LÉON TURNER, "Introduction: Pluralism and Complexity in the Evolutionary Cognitive Science of Religion", in Fraser WatTs and LÉon TuRner, Evolution Religion and Cognitive Science. Critical and Constrictive Essays, Oxford: Oxford University Press 2014, p. 12.

${ }^{44}$ TURNER, "Introduction”, p. 2. 
Sloane Wilson and other cognitive scientists ${ }^{45}$ who recognize culture's causal value. ${ }^{46}$ My proposals are informed by a general idea that three interacting domains: external environment, innate cognitive schemes, and learned cultural patterns form a 'multilayered adaptive landscape" ${ }^{47}$ which determines the cultural success of novel religious phenomena. Novel religious practices that resonate to elements of these domains, such as established religious practices, conceptual structures, cultural patterns, general cognitive constraints, environmental and economic needs, etc., are, ceteris paribus, better equipped for surviving the process of cultural transmission than others. In other words, novel cultural practices can be "stabilized by dint of cultural mechanisms and cognitive by-products." ${ }^{38}$ An advantage of this model is that by placing cultural elements among two other components of the "adaptive landscape" it moderates the scholar's tendency to over-emphasize their explanatory force. Otherwise it is a very general and, indeed, unsurprising idea. Its more interesting development is investigating what precisely "to resonate" means, what these structures are, and how exactly they influence the stability of religious phenomena. This is a grand interdisciplinary enterprise, only starting to assume its shape. The project involves a scale of complex issues ranging from, "nature-nurture" relationship, maturationally and practiced natural cognitions, culture-specific behavioral patterns and values, dynamics of concepts and conceptual systems' coalescing and many others. I am able to touch upon this issue only in a rather unsystematic way, after making two pragmatic decisions.

Research indicates a relatively stable influence of cognitive constraints on religious representations across local contexts. ${ }^{49}$ In this light I will understand the constraints

${ }^{45}$ Sorensen, Religion, Evolution and the Immunology of Cultural Systems, p. 61-73; Justin L. BARRETt, "Theological Correctness: Cognitive Constrains and the Study of Religion", Method \& Theory in the Study of Religion 11 (4, 1999): p. 325-339; NATHANIEL F. BARRETT, "Toward an Alternative Evolutionary Theory of Religion: Looking Past Computational Evolutionary Psychology to a Wider Field of Possibilities", Journal of the American Academy of Religion 78 (3, 2010): p. 583621; Konrad Talmont-Kaminski, Religion as Magical Ideology: How the Supernatural Reflects Rationality, Durham: Acumen 2013, 160 p.; Jeppe S. Jensen, "Framing Religious Narrative: Cognition and Culture Theoretically", in Armin W. GeErTz and Jeppe S. Jensen (eds.), Religious Narrative, Cognition and Culture: Image and Word in the Mind of Narrative, London, Oakville: Equinox 2011, 336 p.; SloAn Wilson, Darwin's Cathedral, 268 p.

${ }^{46}$ Culture will be understood here as "information capable of affecting individuals' behavior that they acquire from other members of their species throughout teaching, imitation, and other forms of social transmission." Peter J. Richerson and Robert Boyd, Not by Genes Alone: How Culture Transforms Human Evolution, The University of Chicago Press 2006 (first published 2005), 332 p.

47 “The term 'multilayered adaptive landscape' is used here to capture both the massive evolutionary background of human experience and its constant fluidity. On the one hand it is intended to convey the vast depths of inorganic, organic, cultural, social, and semiotic structures that underlie and shape the contours of experience. On the other hand, it is intended to convey the interactive nature of experience as a dynamic process[.]” BARETT, "Toward an Alternative Evolutionary Theory of Religion", p. 603.

48 Talmont-Kaminski, Religion as Magical Ideology, p. 8.

${ }^{49}$ Boyer, The Naturalness of Religious Ideas, 324 p.; BOyer, Religion Explained, 375 p.; PAsCAL BoyER, The Fracture of an Illusion: Science and the Dissolution of Religion, Götingen: Vandenhoeck \& Ruprecht 2011, 112 p.; Pascal Boyer and Charles Ramble: "Cognitive Templates for Reli- 
as a broad frame embedding and interacting with specific cultural determinants. I believe that by specification of various cultural frameworks, with an eye on limitations posed by cognitive constrains, ${ }^{50}$ it can be possible to describe, with reasonable precision, complex causal embedding of particular religious phenomena.

Secondly, since McDaniel's study develops around isomorphism between cultural values and characters of religious objects, practices, and personages, I will also focus on isomorphism between religious phenomena and the adaptive landscape as one possible stabilizing principle. The decision, however, is not merely pragmatic. It is feasible that similarity with established cultural patterns makes a religious practice or idea seem familiar, feel natural, and thus increase its chances at recall, perpetuation, and attribution of efficacy. Besides, if these patterns are adaptations, the novel practice reinforces them and increases thus the host culture and its own chances to survive. ${ }^{51}$

\section{Seeing the wat}

A Thai wat is usually a vivid compound bursting with buildings, effigies, structures, visuals, natural objects, and signs untamed by official rules of arrangement. Scholars typically divide this multitude into two basic areas - the "monks' place" (P. sanghāvā$s a$; T. sanghāwāt, สังฆาวาส) and "the Buddha's place" (P. buddhāvāsa; T. phutthāwāt, พุทธาวาส). The former consists primarily of monks' dormitories and the uposatha hall (T. $b \bar{o} t$, โบสถ์) - the place where the ordination ceremony and fortnightly recitation of monastic rules (P. pātimokkha, T. pāthimōk, ปาฏิโมกข์) takes place. It also marks the difference between the regular wat and a monastic residence - T. samnak song (สำนักสงฆ์).

Buddhāvāsa, on the other hand, is dedicated to public ceremonies. ${ }^{.2}$ It comprises the main stūpa and viharra - the building typically housing the principal Buddha image. Swearer, noting that the above division is not universal, highlights the structural relationship between the stüpa enshrining relics and the main Buddha image, which

gious Concepts: Cross-cultural Evidence for Recall of Counter-intuitive Representations", Cognitive Science 25 (2001): p. 535-564.

${ }^{50}$ It means that if, for example, a phenomenon is explainable on the level of cognitive determinants, a cultural explanation will relate only to its particular form, not its occurrence and persistence. In principle cultural forces can offset the cognitive constraints, such as when extra-cranial media can store and transmit cognitively costly concepts unfit for successful transmission. But these cases must be compatible with general cognitive theories.

${ }^{51}$ In principle every anthropological theory proposes a wider "background" which stabilizes studied phenomena. In Terwiel's account discussed above the similarity with "animistic" beliefs makes certain aspects of Theravāda Buddhism more stable. However, the character of these backgrounds may differ dramatically with regard to their actual explanatory power.

52 See Pierre Richard, “The Thai Monastery”, in Pierre Pichard and François Lagirarde (eds.), The Buddhist Monastery: A Cross-Cultural Survey, Paris: École française d'extrême-orient 2003, p. 105-110; Donald K. Swearer, Becoming the Buddha: The ritual of Image Consecration in Thailand, Delhi: Motilal Banarsidass 2004, p. 32. 
in some Thai wats stand next to each other as "correlative signs of the Buddha's presence". ${ }^{53}$ As he explains:

"In Thai wats a mutually symbiotic relationship pertains between reliquary and image, although the close association between stüpa enshrined relics and temple images is not unique to Thailand." 54 "Architecturally, chedi and image hall within the Thai Buddhist wat share an axial proximity." ${ }^{55}$ Since the stūpa enshrines relics its primary function is to make the Buddha indexically present through physical connection with the historical Buddha. This re-presenting function of the stūpa is strengthened by its spatial proximity to the main visual representation of the Buddha - the principal Buddha statue. Also O'Connor, as quoted in Pichard, ${ }^{56}$ reports that it is prevailingly the principal Buddha's image that monks consider the most sacred place in the wat, though some of them give as the holiest place the stūpa (T. chedī, เจดีย์).

Two ripples spoil the clear account. The first one is doubtful claim of the universal centrality of the Buddha image and "Buddhist" ritual practices. McDaniel notes, with regard to the wat he had studied, that "it is becoming hard to tell if Buddha images in wat Mahabhut are drawing legitimacy from Mae Nak or vice versa" ${ }^{57}$

Secondly, it is not clear where, given the absence of an officially sanctioned or universally accepted layout of Thai wat, these arrangements are encoded. Who, apart from scholars, sees them in the described way? Only a few of my informants knew, or recognized in any practical sense, the distinction between sanghāwāt and phutthāwāt, and I have met no one aware of the structural relation between the stüpa and the principal statue of the Buddha described by Swearer.

The belief in a stable meaning behind the standardized religious behavior has been misdirecting studies of religion for long decades. Ritual is probably the most telling example ${ }^{58}$ but the same holds true for other facets of religion. Take for example the Buddhist soteriology. Buddhist texts provide a mass of intricate ontological rationales for the soteric value of meditation by describing how the "outside" world depends on our epistemic structures. But these conceptions are totally ignored in actual meditative practice. Virtually no Thai monastic or lay meditators are familiar with this conceptual underpinning of meditation, and the practice is being perpetuated without its help. Buddhist philosophy, simply, is more "philosophy" than "Buddhist" and the doctrinal meaning is not where the believers' acts make the best sense. ${ }^{59}$

${ }^{53}$ SweArer, Becoming the Buddha, p. 35-45.

${ }^{54}$ SWEARER, Becoming the Buddha, p. 35.

${ }_{55}$ SwEArer, Becoming the Buddha, p. 38.

${ }^{56}$ PICHARD, "The Thai Monastery", p. 103.

57 Justin M. McDaniel, “The Agency between Images: The Relationship among Ghosts, Corpses, Monks, and Deities at a Buddhist Monastery in Thailand", a talk given at the International Conference: Buddhist Narrative in Asia and Beyond. 9-11 August 2010, Bangkok Thailand (transcript), p. 4. Mae Nāk (แม่นาก) is a famous Thai ghost believed to be buried in the wat, and worshiped there.

${ }^{58}$ BOyer, The Fracture of an Illusion, $112 \mathrm{p}$.

${ }^{59}$ I am not suggesting that ritual doesn't evoke any "reading” from part of the participants. Only that this reading is not necessarily identical with its doctrinal explanation. 
Visitors come to a wat to participate in this or that ritual and/or to find "peace of mind". Altogether these are activities revolving around objects other than those studied by art historians, theologians, or students of Buddhist philosophy. Except for great annual festivals such visits are irregular and a matter of immediate needs. Since neither the ritual complexes nor the institution of the wat itself imply a regular attendance it becomes understandable that creating and advertising opportunities to fulfill these needs will stay higher on wats' agenda then doctrinal education.

\section{Advertising versus propaganda}

The distinction between advertising and propaganda which I will keep throughout the text reflects the difference between universal and local frames of reference. Propaganda, concerned with conversion and reinforcing ideology promotes abstract ideas while advertising, highlighting the local opportunities to act within these established systems, points to local objects and events.

Let's take an example. The large billboard by the road from the Suvarnabhumi airport in Bangkok, a product of the "5000s" organization, reads "To use Buddha as a decoration or tattoo means no respect. Don't sell or buy Buddha" and "It is wrong to use Buddha as decoration or tattoo", illustrates propaganda. The billboard states what is right and wrong and attempts to change people's attitude towards Buddha images. Monks' appearance falls into the same category. Seemingly a trifling matter has persistently been a key concern of the Buddhist sangha. As a scholar has noted "This issue is essential because the dignity and aloofness of the monk is linked to how he looks and how he behaves." ${ }^{\prime 0}$ Economic dependency of the sangha on laity had made it imperative that "the monks had to be, or at least appear as, pure and distinguished individuals." ${ }^{11}$ With growing extrinsic motivations for entering the sangha the importance of monks' appearance has also increased. As it is specific values - unity, trustfulness, moderation, peacefulness, non-confrontation - that the monks' appearance promotes it also represents propaganda. A nun (T. maechi, แม่ชี) explaining the importance of the monks and nuns' proper comportment expresses the same idea: "We have to think about society because many of them come and stay here. So we must be careful in order to give them faith in Buddhism. Suppose they think that phra [monks] and mae chee sitting like this is not good then we'll have been the cause of them losing faith in Buddhism. If we stay in the monastery we can relax a bit because we know that there is no danger, but if a lay person is watching we must be careful because of them." ${ }^{2}$

${ }^{60}$ Torkel Brekke, Religious Motivation and the Origins of Buddhism: A Social-Psychological Exploration of the Origins of a World Religion, London, New York: Routledge 2002, p. 39.

${ }^{61}$ BREKKe, Religious Motivation and the Origins of Buddhism, p. 26.

${ }^{62}$ Joanna Cook, Meditation in Modern Buddhism: Renunciation and Change in Thai Monastic Life, Cambridge, New York: Cambridge University Press 2010, p. 131. 
That advertising, as defined here, enjoys a much stronger presence in the Thai religious context then propaganda underlies the primarily local focus of Thai Buddhism and underscores the importance of the local frame of reference for understanding this "universal religion". Here are a few examples of public religious representations highlighting "transitory locals" rather than "enduring ultimates": the images of the Buddha on billboards, posters or banners are virtually always photographs or pictures of particular Buddha statues, not representations of the Buddha as a historical or mythological figure. These visuals remind us primarily of the places where the statues reside and the powers they inhere. The principal Buddha statues at wats are often individualized by some visual detail by which they are often known (red lips, sunglasses), ${ }^{63}$ likings for a specific kind of offering (boiled eggs, small dancing figures), stories of their origin or installation, and specific powers they wield. Famous Buddha statues are replicated over and over again, thus representing across time and space not the Buddha himself but the particular effigy. McDaniel also notes that "people are so dedicated to certain images that they actually sacrifice themselves or harm themselves to honor the image." ${ }^{64}$

Not only Buddha statues, but also pictures of famous Thai monks outstrip the representations of the Buddha in terms of their presence across the Thai visual landscape.

The universal symbolic codes studied by the Iconography "identifying types of visual motifs and attributing particular meanings to them" ${ }^{65}$ are in practical context offset by the objects' idiosyncratic features. The legitimacy of these effigies, the fact that they are installed, worshiped, or even noted, may depend on very local conditions, their associations with other effigies or sources of supernatural powers. ${ }^{66}$

With this distinction in mind we can have a look at some specific examples of Thai religious advertising.

The second part of the study will be published in CEJCR, issue 2 (Fall 2017).

\section{REFERENCES}

Thai references

GAEWTHĀRĀ, “Sadekhrè” Duei Ton Ēng Hen Phon Than Tā, Samnak Pim Yōn Rēi 2013. (แก้วธารา, “สะเดาะเคราะห์” ด้วยตนเอง เห็นผลทันตา, สำนักพิมพ์ย้อนรอย 2013.)

${ }^{63}$ Thus for example wat Phrāmanī (วัดพรามห์มณี) is better known as wat Luangpe Pākdaeng (หลวง พ่อปากแดง) due to the red-painted lips ( $p \bar{a} k d a e n g$ ) of its principal Buddha statue.

${ }^{64}$ McDAniel, The Lovelorn Ghost and the Magical Monk, p. 167. McDaniel doesn't explain what kind of self-sacrifice he has in mind. I am unfamiliar with human self-sacrifice in honor of the statue of Buddha in the contemporary history though royal chronicles and decrees of King Mongkut (r. 1851-1868) record such acts.

${ }^{65}$ MARION G. MÜLler, "Iconography and Iconology as a Visual Method and Approach", in ERIC Margolis and Luc Pauwels (eds.), The Sage Handbook of Visual Research Methods, Los Angeles: Sage Publications Ltd. 2011, p. 288.

${ }^{66}$ See McDaniel, The Lovelorn Ghost and the Magical Monk, esp. chapter 4. 
SAWATPHĀNIT, Gē, Lagsana Sanghom Thai, in Phanēk Isara Sangkom Vithaiā Lae Mānusaiavithaiā Mahāvithaiālai Thammasāt, Rāingān Gān Sammanā Thāng Vichāgān Rtrang Lagsana Sangkhom Thai, HJG. Gān Phim Phranakhon, 1979.

(สวัสดิ์พาณิชย์, ก่อ, ลักษณะสังคมไทย, in แผนกอิสระสังคมวิทยาและมานุษยวิทยา มหาวิทยาลัย ธรรมศาสตร์, รายงานการสัมมนาทางวิชาการ เรื่อง ลักษณะสังคมไทย, หจก. การพิมพ์พระนคร 1979.)

KHRUAGAEW NA LAMPHŪN, PHAITHUN, Lagsana Sangkom Thai, Nāi Yōt Ying Sōphon Phū Phim Phū Khōsanā 1975.

(ไพฑูรย์ เครือแก้ว ณ ลำพูน, ลักษณะสังคมไทย, นายยอดยิ่ง โสภน ผู้พิมพ์ผู้โมษณา 1975.)

SUTTHIPAN, S., Gae Gam Phon Thuk Ānisong Haeng Satthā Jāk Luang Pū Rung Thung Phra Ājān Uthēn, Borisat Sathāpon Buk Jamgat 2009.

(สุทธิพันธ์, ส., แก้กรรม พ้นทุกข์ อานิสงส์แห่งศรัทธา จากหลวงปู่รุ่งถึงพระอาจารย์อุเทน, บริษัท สถาพรบุ๊คส์ จำกัด 2009.)

\section{English references}

“Global Peace Index 2016” (online), Institute for economics and Peace, accessed June 2016, available online at http://static.visionofhumanity.org/sites/default/files /GPI\%202016\%20Report_2.pdf.

Atran, ScotT, In Gods We Trust: The Evolutionary Landscape of Religion, New York: Oxford University Press 2004, 400 p.

Bailey, Greg, and Ian Mabbett, The Sociology of Early Buddhism, Cambridge: Cambridge University Press 2003, 284 p.

Barrett, Justin L., "Cognitive Constraints on Hindu Concepts of Divine”, Journal for the Scientific Study of Religion 37 (4, 1998): p. 608-619.

BARrett, Justin L., "Theological Correctness: Cognitive Constrains and the Study of Religion", Method \& Theory in the Study of Religion 11 (4, 1999): p. 325-339.

Barrett, Justin L., "Bringing Data to Mind: Empirical Claims of Lawson and McCauley's Theory of Religious Ritual”, in T. Light and B. C. WiLson (eds.), Religion as a Human Capacity: A Festschrift in Honor of E. Thomas Lawson, Leiden, Boston: Brill 2004, p. 265-288.

Barrett, Nathaniel F., "Toward an Alternative Evolutionary Theory of Religion: Looking Past Computational Evolutionary Psychology to a Wider Field of Possibilities", Journal of the American Academy of Religion 78 (3, 2010): p. 583-621.

Boddнi, Bнiккнu, The Numerical Discourses of the Buddha: A Translation of the Anguttara Nikaya, Boston: Wisdom Publications 2012, 1924 p.

Boyer, Pascal, “Cognitive Aspects of Religious Symbolism”, in Pascal Boyer (ed.), Cognitive Aspects of Religious Symbolism, Cambridge, New York: Cambridge University Press 1993, p. 4-47.

Boyer, Pascal, and Charles Ramble, "Cognitive Templates for Religious Concepts: Cross-cultural Evidence for Recall of Counter-intuitive Representations”, Cognitive Science 25 (2001): p. 535-564.

Boyer, Pascal, Religion Explained: The Evolutionary Origins of Religious Thought, New York: Basic Books 2001, 375 p.

Boyer, Pascal, The Fracture of an Illusion: Science and the Dissolution of Religion, Götingen: Vandenhoeck \& Ruprecht 2011, 112 p.

Boyer, PAscal, The Naturalness of Religious Ideas: A Cognitive Theory of Religion, Berkeley: University of California Press 1994, 324 p.

Brekke, Torkel, Religious Motivation and the Origins of Buddhism: A Social-Psychological Exploration of the Origins of a World Religion, London, New York: Routledge 2002, $150 \mathrm{p}$. 
Connors, Michael K., Democracy and National Identity in Thailand, New York, London: RoutledgeCurzon 2005, first published 2003, 275 p.

Cook, Joanna, Meditation in Modern Buddhism: Renunciation and Change in Thai Monastic Life, Cambridge, New York: Cambridge University Press 2010, 214 p.

D'Andrade, Roy G., "Schemas and Motivations", in Roy G. D'Andrade and Claudia STRAuss (eds.), Human motives and Cultural Models, Cambridge: Cambridge University Press 1997 (first published 1992), p. 23-44.

Engel, David M., and Jaruwan D. Engel, Tort, Custom, and Karma: Globalization and Legal Consciousness in Thailand, Stanford: Stanford University Press 2010, 190 p.

Evans, Jonathan S., "Dual-Processing Accounts of Reasoning, Judgment, and Social Cognition”, in Annual Review of Psychology, 59 (2008): p. 255-278.

Geertz, Armin W., "The Meaningful Brain: Clifford Geertz and the Cognitive Science of Culture", in Dimitris Xygalatas and William W. McCorkle (eds.), Mental Culture: Classical Social Theory and the Cognitive Science of Religion, Durham: Acumen 2013, p. 176-196.

GeERTZ, Clifford, The Interpretation of Cultures, New York: Basic Books 2000 (first published 1973), $470 \mathrm{p}$.

GOMBRICH, RICHARD, “Recovering the Buddha's Message”, Buddhist Forum (1), London: SOAS 1990, p. 5-20.

Gombrich, Richard, How Buddhism Began: The Conditioned Genesis of the Early Teachings, London, New York: Routledge 2006 (first published 1996), 180 p.

Gombrich, Richard: Theravāda Buddhism: A social History from Ancient Benares to Modern Colombo, London, New York: Routledge 1988, 237 p.

Haidt, Jonathan, The Righteous Mind: Why Good People are Divided by Politics and Religion, New York: Vintage 2012, 528 p.

Hanks, Lucien M., Jr., "Merit and Power in the Thai Social Order", American Anthropologist New Series 64 (6, 1962): p. 1247-1261.

Holt, Clifford, Spirits of Place: Buddhism and Lao Religious Culture, Honolulu: University of Hawaii 2009, 348 p.

Jackson, Peter A., “Withering Centre Flourishing Margins. Buddhism's Changing Political Roles", in Kevin Hewison, (ed.), Political Change in Thailand. Democracy and Participation, London, New York: Routledge 1997, p. 75-93.

Jensen, Jeppe S., "Framing Religious Narrative: Cognition and Culture Theoretically", in Armin W. Geertz and Jeppe S. Jensen (eds.), Religious Narrative, Cognition and Culture: Image and Word in the Mind of Narrative, London, Oakville: Equinox 2011, $336 \mathrm{p}$.

KamkeE-An Suvanno, Watching: Not 'Being': Developing Awareness According to the Practice of Loo-ang Por Tee-an Cittasubho, compiled and translated by Venerable Tone (Tony) Jinavamso (Antoine van der Bom), 2006.

Kirsch, Thomas A., "Complexity of Thai Religious System”, The Journal of Asian Studies 36 (2, 1977): p. 241-266.

Kitiarsa, Pattana, "Beyond Syncretism: Hybridization of Popular Religion in Contemporary Thailand”, Journal of Southeast Asian Studies 36 (3, 2005): p. 461-487.

Kitiarsa, Pattana, "Buddha Phanit: Thailand's Prosperity Religion and its Commodifying Effect”, in Pattana Kitiarsa (ed.): Religious Commodifications in Asia: Marketing Gods, London, New York: Routledge 2008, p. 120-143.

Kitiarsa, Pattana, Mediums, Monks, and Amulets: Thai Popular Buddhism Today, Chiang Mai: Silkworm Books 2012, 170 p.

Komin, Suntaree, Psychology of Thai People: Values and Behavioral Patterns, Bangkok: NIDA 1990, 359 p. 
Kumer, Hans, "Causal Knowledge in Animals", in Dan Sperber, David Premack and Ann J. Premack, Causal Cognition: A Multidisciplinary Debate, Oxford: Clarendon Press, New York: Oxford University Press 2002 (first published 1995), p. 26-36.

LANGER, Rita, Buddhist Rituals of Death and Rebirth: Contemporary Sri Lankan Practice and its Origins, London, New York: Routledge 2007, 243 p.

Lawson, Thomas, "Explanatory Pluralism and the Cognitive Science of Religion", in Dmitris Xygalatas and William W. McCorkle Jr. (eds.) Mental Culture. Classical Social Theory and the Cognitive Science of Religion, Durham: Acumen 2013, p. 11-32.

Masuda, T., and R. E. Nisbet, Culture and Attention to Object vs. Field, unpublished manuscript, University of Michigan 2001.

Matics, K. I., Gestures of the Buddha, Bangkok: Chulalongkorn University Press 2004, $295 \mathrm{p}$.

McDaniel, Justin T., "Buddhism in Thailand. Negotiating the Modern Age", in Stephen C. Berkwitz (ed.), Buddhism in World Cultures: Comparative Perspectives, Santa Barbara: ABC-CLIO 2006, p. 101-128.

McDaniel, Justin T., "The Agency between Images: The Relationship among Ghosts, Corpses, Monks, and Deities at a Buddhist Monastery in Thailand", a talk given at the International Conference: Buddhist Narrative in Asia and Beyond, 9-11 August 2010, Bangkok Thailand (transcript).

McDaniel, Justin T., Gathering Leaves \& Lifting Words: Histories of Buddhist Monastic Education in Laos and Thailand, Seattle: University of Washington Press 2008, 358 p.

McDaniel, Justin T., The Lovelorn Ghost and the Magical Monk, New York: Columbia University Press 2011, 327 p.

McDermott, James P., "Sādhīna Jātaka: A Case against the Transfer of Merit”, Journal of the American Oriental Society 94 (3, 1974), p. 385-387.

McDermott, James P., Development in the Early Buddhist Concept of Kama/Karma, New Delhi: Munshiram Manoharlal Publishers Pvt. Ltd. 2003 (first published 1984), 185 p.

Mole, Robert L., Thai Values and Behavior Patterns, Rutland: Charles E. Tuttle Company 1973, 182 p.

Morris, BriAn, Religion and Anthropology, New York: Cambridge University Press 2006, $350 \mathrm{p}$.

Mulder, Niels, Everyday Life in Thailand: An Interpretation, Bangkok: Duang Kamol $1979,223 \mathrm{p}$.

Mulder, Niels, Inside Southeast Asia. Thai Javanese and Filipino Interpretations of Everyday Life, Bangkok: Duang Kamol 1992, 178 p.

MüLler, MARION G., "Iconography and Iconology as a Visual Method and Approach", in Eric Margolis and Luc Pauwels (eds.), The Sage Handbook of Visual Research Methods, Los Angeles: Sage Publications Ltd. 2011, p. 283-297.

Nisbett, Richard E., Kaiping Peng, Incheol Choi and Ara Norenzayan, "Culture and Systems of Thought: Holistic Versus Analytic Cognition”, Psychological Review 108 (2, 2001): p. 291-310.

Norris, Pippa, and Ronald Inglehart, Sacred and Secular: Religion and Politics Worldwide, Cambridge, New York: Cambridge University Press 2004, 329 p.

O'Connor, Richard A., "Centers of Sanctities, Regions and Religion: Varieties of Thai Buddhism", communication at the Annual Meeting of the American Anthropological Association, Washington D.C. 1985, 26 p.

O'Connor, Richard A., "Interpreting Thai Religious Change: Temples, Sangha Reform and Social Change", Journal of Southeast Asian Studies 24 (2, 1993), p. 330-339.

Obeysekere, Gananath, "The Great Tradition and the Little", The Journal of Asian Studies 22 (2, 1963): p. 139-153. 
Obeysekere, Gananath, Imagining Karma. Ethical Transformation in Amerindian, Buddhist, and Greek Rebirth, Berkeley: University of California Press 2002, $448 \mathrm{p}$.

Ockey, James, Making Democracy: Leadership, Class, Genders, and Political Participation in Thailand, Chiang Mai: Silkworm Books 2004, 244 p.

Paden, William E., "Connecting with Evolutionary Models", in Villi Braun and Russell T. McCutcheon (eds.), Introducing Religion. Essays in Honor of Jonathan Z. Smith, London, Oakville: Equinox Publishing 2008, p. 416-417.

Paden, William E., "The Prestige of the Gods: Evolutionary Continuities in the Formation of Sacred Objects", in Armin W. Geertz (ed.), Origins of Religion, Cognition and Culture, Durham: Acumen 2013, p. 82-97.

Paden, William E., New Patterns for Comparative Religion: Passages to an Evolutionary Perspective, London, New York: Bloomsbury Academic 2016, 253 p.

Pemaratana, Soorakkulame, "Evolution of the Theravāda Buddhist Idea of 'Merittransference' to the Dead, and its Role in Sri Lankan Buddhist Culture”, Buddhist Studies Review 30 (1, 2013), p. 89-112.

Pichard, Pierre, “The Thai Monastery”, in Pierre Pichard and François Lagirarde (eds.), The Buddhist Monastery: A Cross-Cultural Survey, Paris: École française d'extrême-orient 2003, p. 93-118.

Pyysiäinen, Ilka, How Religion Works: Towards and New Cognitive Science of Religion, Leiden, Boston: Brill 2003, 272 p.

PyysiäInen, Ilka, Supernatural Agents: Why We Believe in Souls, Gods, and Buddhas, Oxford, New York: Oxford University Press 2009, 285 p.

Richerson, Peter J., and Robert Boyd, Not by Genes Alone: How Culture Transforms Human Evolution, The University of Chicago Press 2006 (first published 2005), 332 p.

Ridley, Matt, The Origins of Virtue: Human Instincts and the Evolution of Cooperation, Penguin Books 1996, 297 p.

Schwartz, Shalom H., "Basic human values: Their content and structure across countries", in A. TAMAYo and J. B. PoRto (eds.), Valores e comportamento nas organizações, Petrópolis: Vozes 2005, p. 21-55.

Schwartz, Shalom H., "Universals in the Content and Structure of Values: Theoretical Advances and Empirical Tests in 20 Countries" (online), Advances in Experimental Social Psychology 25 (1992), accessed May 2016, available online at http://kodu.ut.ee/ cect/teoreetiline\%20seminar\%2023.04.2013/Schwartz\%201992 .pdf.

Simpson, Andrew, and Noi Thammasathien, "Laos and Thailand", in Andrew Simpson (ed.), Language and National Identity in Asia, Oxford, New York: Oxford University Press 2007, p. 391-414.

Sørensen, Jesper, "Charisma, Tradition, and Ritual. A Cognitive Approach to Magical Agency”, in Harvey Whitehouse and Robert M. McCauley (eds.) Mind and Religion. Psychological and Cognitive Foundations of religion, Lanham: Altamira Press 2005, p. 167-186.

Sørensen, Jesper, "Religion, Evolution, and the Immunology of Cultural Systems", Evolution and Cognition 210 (1,2004): p. 61-73.

Sørensen, Jesper, A Cognitive Theory of Magic, Lanham: Altamira Press 2007, 218 p.

Sperber, DAN, "Apparently Irrational Beliefs", in MARTin Hollis and Steven Lukes (eds.), Rationality and Relativism, Oxford: Blackwell Publishers 1993 (first published 1983), p. 149-180.

Sperber, DAN, Rethinking Symbolism, Cambridge, New York: Cambridge University Press $1975,153 \mathrm{p}$. 
Spiro, Melford E., "Religion: Problems of definition and Explanation", in Michael Banton (ed.), Anthropological Approaches to the Study of Religion. London, New York: Routledge 2004 (first published 1966), p. 85-126.

Spiro, Melford E., Buddhism and Society: A Great Tradition and its Burmese Vicissitudes, Second expanded edition, Berkeley: University of California 1982 (first published 1970), $510 \mathrm{p}$.

Swearer, Donald K., Becoming the Buddha: The ritual of Image Consecration in Thailand, Delhi: Motilal Banarsidass 2004.

Talmont-Kaminski, KonRad, Religion as Magical Ideology: How the Supernatural Reflects Rationality, Durham: Acumen 2013, 160 p.

Tambiah, Stanley J., Buddhism and the Spirit Cults in North-east Thailand, Cambridge University Press 1970, 388 p.

Tambiah, Stanley J., The Buddhist saints of the Forest and the Cult of Amulets: A Study in Charisma, hagiography, Sectarianism, and Millennial Buddhism, Cambridge, New York: Cambridge University Press 1984, 417 p.

TAylor, James, “(Post-) Modernity, Remaking Tradition, and the Hybridisation of Thai Buddhism”, Anthropological Forum 9 (2, 1999), p. 163-187.

TAylor, James, "Cyber-Buddhism and Changing Urban Space in Thailand” (online), Space and Culture 6 (3, 2003; accessed May 2016): p. 292-308, available online at http://sac.sagepub.com/cgi/content/abstract/6/3/292.

Taylor, James, “Understanding Social Realities: Stanley Tambiah’s Early Contribution to Sociology of Thai Buddhism”, in Felicity Aulino, Miriam Goheen and Stanley J. ТАмвінн (eds.), Radical Egalitarianism: Local Realities, Global Relations, New York: Fordham University Press 2013, p. 51-67.

Terwiel, BARend J., "A Model for the Study of Thai Buddhism”, The Journal of Asian Studies 35 (3, 1976): p. 391-403.

Terwiel, Barend J., Monks and Magic: An Analysis of Religious Ceremonies in Central Thailand, Third Revised edition, Bangkok: White Lotus 1994 (first published 1975), $302 \mathrm{p}$.

ThānIssaro, The Buddhist Monastic Code: The PātimokkhaTraining Rules Translated and Explained, The Mahāmaḳuta Educational Council 1993.

Turner, LÉon, "Introduction: Pluralism and Complexity in the Evolutionary Cognitive Science of Religion”, in Fraser WatTs and LÉON TURner, Evolution Religion and Cognitive Science. Critical and Constrictive Essays, Oxford: Oxford University Press 2014, p. 1-20.

Whitehouse, Harwey, "Modes of Religiosity: Towards a Cognitive Explanation of the Sociopolitical Dynamics of Religion", Method \& Theory in the Study of Religion 14 (2002): p. 293-315.

Wilson, David Sloan, Darwin's Cathedral: Evolution, Religion, and the Nature of Society, Chicago: The University of Chicago Press 2002, 268 p.

Wittgenstein, Ludwig, Philosophical Occasions 1912-1951, edited by James KLAGge and Alfred Nordman, Indianapolis: Hackett Publishing 1993, p. 193.

Xygalatas, Dimitris, and William W. McCorkle (eds.), Mental Culture: Classical Social Theory and the Cognitive Science of Religion, Durham: Acumen 2013, 268 p. 